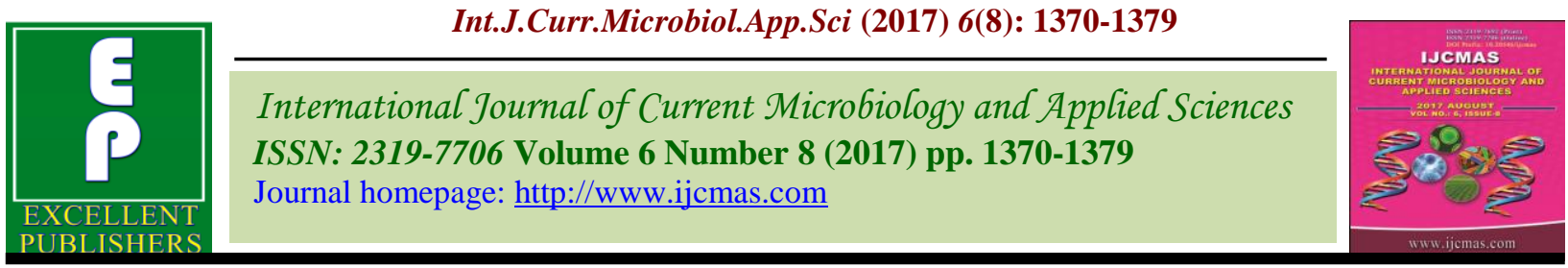

Original Research Article

https://doi.org/10.20546/ijcmas.2017.608.167

\title{
Studies of Various Packaging Materials and Waxing on Quality Traits of Kinnow
}

\author{
Rupinder Singh, Senthil Kumar, Anjil Kumar*, Sudhir Pratap, \\ Davinder, Harmanbir Singh and Ajay Kumar
}

\author{
Department of Horticulture, School of Agriculture, Lovely Professional University, \\ Phagwara 144401, Punjab, India \\ *Corresponding author
}

\author{
A B S T R A C T
}

\begin{tabular}{|c|c|}
\hline $\begin{array}{l}\text { Polypropylene, } \\
\text { Shrink, Cling, } \\
\text { Ambient } \\
\text { temperature, } \\
\text { Kinnow. }\end{array}$ & $\begin{array}{l}\text { An investigation was conducted at post-harvest laboratory, Department of Horticulture, } \\
\text { Lovely Professional University, Punjab during the academic year } 2016-17 \text { to study the } \\
\text { effect of various packaging materials on fruit quality and shelf life of Kinnow. The } \\
\text { packaging films include LDPE ( } 25 \text { micron), HDPE ( } 15 \text { micron), Polypropylene }(25 \\
\text { micron), Shrink film ( } 15 \text { micron) and Cling film ( } 15 \text { micron) were used for } \\
\text { experimentation. Liquid paraffin wax }(10 \%) \text { was used as a coating material. The fruits } \\
\text { were then kept at ambient temperature. In case of quality related traits, the fruits under }\end{array}$ \\
\hline Article Info & \\
\hline $\begin{array}{l}\text { Accepted: } \\
17 \text { June } 2017 \\
\text { Available Online: } \\
10 \text { August } 2017\end{array}$ & $\begin{array}{l}\text { storage. With regard to remaining quality related traits, the fruits under treatment } \mathrm{T}_{11} \\
\text { (Cling film at } 15 \text { micron }+ \text { wax at } 10 \% \text { ) expressed the maximum value for "TSS: acid } \\
\text { ratio", Total sugars", "Non-reducing sugars" and "Sugar: acid ratio" at } 25 \text { th day after } \\
\text { storage. }\end{array}$ \\
\hline
\end{tabular}

\section{Introduction}

Citrus fruits are grown commercially in tropics and subtropic regions of the world. Kinnow, a mandarin hybrid (King x Willow leaf) occupies the prime position amongst the citrus fruits grown in India. In subtropical regions of Punjab, it occupies around 50\% area of fruit growing regions. In Kinnow, improper post-harvest handling practices lead to quality deterioration and fetch poor market price. In mandarin, loss of $20-25 \%$ has been estimated due with transportation of fruits from field to market (PHLRD, 2005). Qualitative losses, in sense of caloric and nutritive value, non-acceptability by consumers, and poor edibility are more difficult to measure than quantitative losses of fresh fruits. Among for stored fruits, postharvest losses account to 20-30\%. In most of the storability studies for fruits, it is found to be observed that the levels of $\mathrm{CO}_{2}$ and $\mathrm{O}_{2}$ inside package altered due to fruit respiration and permeability of the film, resulted in recommendation of modified atmosphere packaging (MAP) for fresh fruit storage (Geeson et al., 1981). When the rate of oxygen and carbon dioxide transmission through the package equal the product's respiration rate then desirable equilibrium modified atmosphere gets created in the package film at right permeability, edible 
coatings have long been used for quality retention and shelf life extension of several fresh fruits viz., apple, citrus. They have been applied directly on fruit surface with several mode of application viz., dipping, spraying or brushing to create a modified atmosphere (McHugh and Senesi, 2000). Basically the usage of food grade wax coatings on fresh fruits and vegetables have been approved by the Government of India and with implementation of this technology on with several wax formulations are now-a-days being supplied by suppliers in market. So, the impact of these waxes coating plays a vital role in monitoring the storability of fresh fruits, especially kinnow. However, the role of these waxes alone or in combination with packaging needed much focus on correlating the positive mode of applicability to kinnow.

\section{Materials and Methods}

The present investigations were carried out at the horticulture laboratory of Lovely Professional University, Phagwara Punjab, from January to March, 2017.

\section{Selection and harvest of fruits}

The fresh kinnow fruits of uniform size and well matured ones were selected. Apart, other traits of healthiness for fruits free from that of disease and bruising on skin were also taken in consideration for selection of fruits for harvest. The selected fruits were randomly picked from entire direction of the plant with the help of secateurs. The act of fruit harvest commenced during the month of February, collected and brought to Horticulture laboratory.

\section{Details of experiment}

The experiment was laid out in Completely Randomized Design (CRD). A total of 27 fruits per treatment were divided into equal lots for all 3 replications and each of lot under every replication found to be accumulated with 9 fruits. The treated fruits were kept for storage and observed at 5 days interval upto 25 days.

\section{Packaging and coating materials for fruits}

The packaging films used in this experimentation were purchased from Jalandhar commercial market area. The materials include LDPE (25 micron), HDPE (15 micron), Polypropylene (25 micron), Shrink film (15 micron) and Cling film (15 micron). Liquid paraffin wax (10\%) was used as a coating material.

\section{Treatment details}

\begin{tabular}{|c|l|}
\hline Treatments & Treatment Details \\
\hline $\mathrm{T}_{1}$ & Control (Room temperature) \\
\hline $\mathrm{T}_{2}$ & LDPE (25 micron) \\
\hline $\mathrm{T}_{3}$ & HDPE (15 micron) \\
\hline $\mathrm{T}_{4}$ & Polypropylene (25 micron) \\
\hline $\mathrm{T}_{5}$ & Shrink film (15 micron) \\
\hline $\mathrm{T}_{6}$ & Cling film (15 micron) \\
\hline $\mathrm{T}_{7}$ & LDPE (25 micron) + wax (10\%) \\
\hline $\mathrm{T}_{8}$ & HDPE (15 micron) + wax $(10 \%)$ \\
\hline $\mathrm{T}_{9}$ & Polypropylene $(25$ micron) + wax $(10 \%)$ \\
\hline $\mathrm{T}_{10}$ & Shrink film (15 micron) + wax $(10 \%)$ \\
\hline $\mathrm{T}_{11}$ & Cling film (15 micron) + wax $(10 \%)$ \\
\hline
\end{tabular}




\section{Observations recorded}

\section{Chemical parameters}

Randomly selected fruits in each treatment of the experimentation were used for assessing the quality parameters. TSS ( ${ }^{\circ}$ Brix), Titrable acidity, Ascorbic acid (mg/100ml), pH, TSS: acid ratio, Total sugars (\%), Reducing sugars $(\%)$, Non-reducing sugars (\%) and Sugar: Acid. These parameters were determined by the methods described by AOAC.

\section{Statistical Analysis}

The data were subjected to statistical analysis as outlined by Panse and Sukhatme (1985). The various comparisons were made after working out the standard errors and critical difference at 5 per cent level of significance.

\section{Results \& Discussions}

Observations recorded on chemical parameters exhibited significant differences among the treatments in 5,10,15, 20 and 25 days after storage of Kinnow. The data presented in the (tables 1-9) is significant.

Among the packaging treatments, the fruits under the treatment $T_{1}$ retained maximum 'TSS' $\left(11.56^{\circ} \mathrm{B}\right)$, which were on par with each other including $\mathrm{T}_{3}\left(11.10^{\circ} \mathrm{B}\right)$ at 5 days after storage. The minimum 'TSS' was recorded in $\mathrm{T}_{7}\left(10.20^{\circ} \mathrm{B}\right)$. It was found to be on par with $\mathrm{T}_{9}\left(10.50^{\circ} \mathrm{B}\right)$ and $\mathrm{T}_{10}\left(10.60^{\circ} \mathrm{B}\right)$. At 25 days after storage, the observations among various packaging treatments revealed that the fruits under treatment $\mathrm{T}_{11}$ retained maximum 'TSS' $\left(12.20^{\circ} \mathrm{B}\right)$. The minimum 'TSS' was recorded in $\mathrm{T}_{6}\left(11.95^{\circ} \mathrm{B}\right)$, which was on par with $\mathrm{T}_{3}$ $\left(12.00^{\circ} \mathrm{B}\right)$. In rest of the treatments, no fruits were found to be retained for observation. The retention of better TSS value of with the increasing storability could be due to the degradation of complex insoluble compounds, like starch, to simple soluble compounds, like sugars, which acts as the major TSS components. These results are in line with the findings of Efiuvwere and Oyelade (1991) on orange; Kumar et al., (1991) on Kinnow mandarin. And the fruits under the treatment $\mathrm{T}_{1}$ retained maximum 'Titrable acidity' $(1.33 \%)$. The minimum 'Titrable acidity' was recorded in $\mathrm{T}_{7}(1.17 \%)$. At 25days after storage, the observations among various packaging treatments revealed that the fruits under treatment $\mathrm{T}_{6}$ retained maximum 'Titrable acidity' (0.81\%). The minimum 'Titrable acidity' was recorded in $\mathrm{T}_{11}(0.76 \%)$. In rest of the treatments, except $T_{3}$, no fruits were found to be retained for observation. The decline in acidity might be due to conversion of acids into sugars and its utility in respiration process. Results are in line with the results of Sonkar and Ladaniya (1999) in Nagpur mandarin and Mahajan et al., (2005) in kinnow. The fruits under the treatment $\mathrm{T}_{5}$ retained maximum 'Ascorbic acid' (25.58 $\mathrm{mg} / 100 \mathrm{ml}$ ), which were on par with each other including $\mathrm{T}_{2}(25.24 \mathrm{mg} / 100 \mathrm{ml})$ and $\mathrm{T}_{11}(25.16$ $\mathrm{mg} / 100 \mathrm{ml}$ ) at 5 days after storage. The minimum 'Ascorbic acid' was recorded in $\mathrm{T}_{1}$ $(21.33 \mathrm{mg} / 100 \mathrm{ml})$. At 25 days after storage, the observations among various packaging treatments revealed that the fruits under treatment $\mathrm{T}_{6}$ retained maximum 'Ascorbic acid' $(16.04 \mathrm{mg} / 100 \mathrm{ml})$. The minimum 'ascorbic acid' was recorded in $\mathrm{T}_{11}(15.51$ $\mathrm{mg} / 100 \mathrm{ml})$. In rest of the treatments, except $T_{3}$, no fruits were found to be retained for observation. Ascorbic acid content in fruits is known to decrease during storage possibly due to utilization of organic acids during respiration or their conversion to sugars (Kader, 2002). The trend in case of other treatments might be due to the fact that ascorbic acid is very susceptible to oxidative deterioration (Piga et al., 2003). And the fruits under the treatment $\mathrm{T}_{1}$ retained maximum ' $\mathrm{pH}^{\prime}$ (3.90), which were on par with each other including $\mathrm{T}_{9}$ (3.72) and $\mathrm{T}_{7}$ (3.70) at 5 days after 
storage. The minimum ' $\mathrm{pH}$ ' was recorded in $\mathrm{T}_{5}$ (3.42), which were on par with $\mathrm{T}_{2}$ (3.46) and $\mathrm{T}_{11}$ (3.47). At 25days after storage, the observations among various packaging treatments revealed that the fruits under treatment $\mathrm{T}_{11}$ retained maximum $\mathrm{pH}$ (4.17) The minimum ' $\mathrm{pH}$ ' was recorded in $\mathrm{T}_{6}$ (4.06). In rest of the treatments, except $T_{3}$, no fruits were found to be retained for observation. The juice $\mathrm{pH}$ value was gradually increased with the advance in storage period. These results are in line with the findings of ElHefnawi (2002) in mango; El-Hefnawi et al., (2008) in guava; Artés-Hernández et al., (2004, 2006) in grapes. The fruits under the treatment $\mathrm{T}_{3}$ retained maximum 'TSS: Acid ratio' $(9.17)$, which were on par with each other including $\mathrm{T}_{6}(8.85)$ and $\mathrm{T}_{11}(8.86)$ at 5 days after storage. The minimum 'TSS: Acid ratio' was recorded in $\mathrm{T}_{4}$ (8.08). It was found to be on par with $\mathrm{T}_{2}$ and $\mathrm{T}_{10}$ (8.41). At 25days after storage, the observations among various packaging treatments revealed that the fruits under treatment $\mathrm{T}_{11}$ retained maximum 'TSS: Acid ratio' (16.05). The minimum 'TSS: Acid ratio' was recorded in $\mathrm{T}_{6}(14.75)$. In rest of the treatments, except $T_{3}$, no fruits were found to be retained for observation. The higher change in TSS: Acid ratio is straightly related to hydrolytic changes in the starch concentration (conversion of starch to sugars).Manazano and Diaz (2003) reported that 'Valencia' oranges fruits harvested, sorted, graded and treated with a wax coating found that TSS: Acid ratio was increased with the passage of time. Among the packaging treatments, the fruits under the treatment $\mathrm{T}_{1}$ retained maximum 'Total sugars' $(5.82 \%)$ at 5 days after storage. The minimum 'Total sugars' was recorded in $\mathrm{T}_{7}(5.25 \%)$. It was found to be on par with $\mathrm{T}_{4}(5.35 \%)$ and $\mathrm{T}_{9}(5.36 \%)$. At 25days after storage, the observations among various packaging treatments revealed that the fruits under treatment $T_{11}$ retained maximum 'Total sugars' $(6.12 \%)$. The minimum 'Total sugars' was recorded in $\mathrm{T}_{6}(5.88 \%)$. In rest of the treatments, except $T_{3}$, no fruits were found to be retained for observation. The maximum value for sugars might be due to conversion of polysaccharides into soluble sugars, dehydration and transformation of certain cell wall materials like hemicelluloses and pectins and also due to decrease in ascorbic acid content. The results are in line with the findings of Kumar and Chauhan (1990) in mandarin; Haikerwal (2001) in Jaffa sweet orange. And the fruits under the treatment $\mathrm{T}_{7}$ retained maximum 'Reducing sugars' $(3.51 \%)$, which was on par with each other including $\mathrm{T}_{5}$ (3.41\%), $\mathrm{T}_{6}(3.35 \%)$ and $\mathrm{T}_{11}(3.35 \%)$ at 5 days after storage. The minimum 'Reducing sugars' was recorded in $\mathrm{T}_{1}(2.93 \%)$. It was found to be on par with $\mathrm{T}_{10}(3.11 \%)$. At 25 days after storage, the observations among various packaging treatments revealed that the fruits under treatment $\mathrm{T}_{6}$ retained maximum 'Reducing sugars' $(3.83 \%)$. The minimum 'Reducing sugars' was recorded in $\mathrm{T}_{3}$ (3.14\%). In rest of the treatments, except $T_{11}$, no fruits were found to be retained for observation. The fruits under the treatment $\mathrm{T}_{1}$ retained maximum 'Non-reducing sugars' $(2.89 \%)$ at 5 days after storage. The minimum 'Non-reducing sugars' was recorded in $\mathrm{T}_{7}$ $(1.74 \%)$. It was found to be on par with $\mathrm{T}_{5}$ (1.96\%). At 25days after storage, the observations among various packaging treatments revealed that the fruits under treatment $\mathrm{T}_{11}$ retained maximum 'Nonreducing sugars' $(2.86 \%)$, which was on par with each other including $\mathrm{T}_{3}(2.81 \%)$. The minimum 'Non-reducing sugars' was recorded in $\mathrm{T}_{6}(2.05 \%)$. In rest of the treatments, no fruits were found to be retained for observation. Several internal fruit physiological activities like respiration, transpiration and other metabolic processes enhanced. So, starch gets converted to sugars and reducing sugar quantity increased. 
Table.1 Effect of different packaging materials on 'TSS $\left({ }^{\circ} \mathrm{B}\right)$ ' in Kinnow

\begin{tabular}{|c|c|c|c|c|c|}
\hline \multirow{2}{*}{ Treatments } & \multicolumn{5}{|c|}{ TSS $\left({ }^{\circ} \mathbf{B}\right)$} \\
\cline { 2 - 6 } & 5 DAS & 10 DAS & 15 DAS & 20 DAS & 25 DAS \\
\hline $\mathrm{T}_{1}$ & 11.56 & 12.57 & 14.13 & 0.00 & 0.00 \\
\hline $\mathrm{T}_{2}$ & 10.85 & 11.20 & 11.50 & 12.30 & 0.00 \\
\hline $\mathrm{T}_{3}$ & 11.10 & 11.40 & 11.65 & 12.25 & 12.00 \\
\hline $\mathrm{T}_{4}$ & 10.67 & 10.82 & 11.05 & 11.26 & 0.00 \\
\hline $\mathrm{T}_{5}$ & 10.70 & 10.95 & 11.35 & 11.55 & 0.00 \\
\hline $\mathrm{T}_{6}$ & 10.80 & 11.20 & 11.39 & 11.61 & 11.95 \\
\hline $\mathrm{T}_{7}$ & 10.20 & 10.60 & 11.26 & 11.50 & 0.00 \\
\hline $\mathrm{T}_{8}$ & 10.80 & 11.70 & 11.90 & 12.30 & 0.00 \\
\hline $\mathrm{T}_{9}$ & 10.50 & 10.70 & 11.10 & 12.00 & 0.00 \\
\hline $\mathrm{T}_{10}$ & 10.60 & 10.81 & 11.40 & 11.80 & 0.00 \\
\hline $\mathrm{T}_{11}$ & 10.90 & 11.35 & 11.50 & 11.90 & 12.20 \\
\hline $\mathbf{S E}(\mathbf{d})$ & 0.22 & 0.23 & 0.24 & 0.24 & 0.12 \\
\hline CD $(\mathbf{0 . 0 5 \% )}$ & 0.47 & 0.48 & 0.50 & 0.49 & 0.24 \\
\hline
\end{tabular}

DAS: Days after storage

Table.2 Effect of different packaging materials on 'Titrable Acidity (\%)' in Kinnow

\begin{tabular}{|c|c|c|c|c|c|}
\hline \multirow{2}{*}{ Treatments } & \multicolumn{5}{|c|}{ Titrable Acidity (\%) } \\
\cline { 2 - 6 } & 5 DAS & 10 DAS & 15 DAS & 20 DAS & 25 DAS \\
\hline $\mathrm{T}_{1}$ & 1.33 & 1.19 & 0.93 & 0.00 & 0.00 \\
\hline $\mathrm{T}_{2}$ & 1.29 & 1.14 & 0.98 & 0.96 & 0.00 \\
\hline $\mathrm{T}_{3}$ & 1.21 & 1.15 & 1.03 & 0.95 & 0.78 \\
\hline $\mathrm{T}_{4}$ & 1.32 & 1.16 & 1.05 & 0.98 & 0.00 \\
\hline $\mathrm{T}_{5}$ & 1.25 & 1.10 & 0.99 & 0.91 & 0.00 \\
\hline $\mathrm{T}_{6}$ & 1.22 & 1.13 & 1.04 & 0.97 & 0.81 \\
\hline $\mathrm{T}_{7}$ & 1.17 & 1.12 & 1.03 & 0.96 & 0.00 \\
\hline $\mathrm{T}_{8}$ & 1.24 & 1.17 & 1.09 & 0.98 & 0.00 \\
\hline $\mathrm{T}_{9}$ & 1.22 & 1.06 & 0.94 & 0.91 & 0.00 \\
\hline $\mathrm{T}_{10}$ & 1.26 & 1.11 & 1.01 & 0.95 & 0.00 \\
\hline $\mathrm{T}_{11}$ & 1.23 & 1.09 & 0.99 & 0.92 & 0.76 \\
\hline SE(d) & 0.03 & 0.02 & 0.02 & 0.02 & 0.01 \\
\hline CD $(\mathbf{0 . 0 5 \%})$ & 0.06 & 0.05 & 0.04 & 0.04 & 0.02 \\
\hline
\end{tabular}

DAS: Days after storage 
Table.3 Effect of different packaging materials on 'Ascorbic Acid (mg/100ml)' in Kinnow

\begin{tabular}{|c|c|c|c|c|c|}
\hline \multirow{2}{*}{ Treatments } & \multicolumn{5}{|c|}{ Ascorbic Acid (mg/100ml) } \\
\cline { 2 - 6 } & $\mathbf{5 ~ D A S}$ & $\mathbf{1 0}$ DAS & 15 DAS & 20 DAS & 25 DAS \\
\hline $\mathrm{T}_{1}$ & 21.33 & 17.52 & 12.49 & 0.00 & 0.00 \\
\hline $\mathrm{T}_{2}$ & 25.24 & 22.17 & 19.02 & 17.36 & 0.00 \\
\hline $\mathrm{T}_{3}$ & 23.74 & 21.87 & 19.62 & 17.42 & 15.75 \\
\hline $\mathrm{T}_{4}$ & 23.85 & 21.9 & 19.48 & 17.74 & 0.00 \\
\hline $\mathrm{T}_{5}$ & 25.58 & 22.24 & 19.2 & 17.86 & 0.00 \\
\hline $\mathrm{T}_{6}$ & 24.37 & 21.71 & 19.89 & 18.11 & 16.04 \\
\hline $\mathrm{T}_{7}$ & 23.33 & 21.2 & 18.43 & 17.13 & 0.00 \\
\hline $\mathrm{T}_{8}$ & 24.51 & 22.08 & 18.77 & 17.83 & 0.00 \\
\hline $\mathrm{T}_{9}$ & 23.15 & 21.43 & 18.17 & 16.82 & 0.00 \\
\hline $\mathrm{T}_{10}$ & 24.83 & 22.39 & 19.25 & 17.08 & 0.00 \\
\hline $\mathrm{T}_{11}$ & 25.16 & 22.89 & 19.41 & 17.24 & 15.51 \\
\hline $\mathbf{S E}(\mathbf{d})$ & 0.50 & 0.45 & 0.38 & 0.34 & 0.15 \\
\hline $\mathbf{C D}(\mathbf{0 . 0 5 \%})$ & 1.04 & 0.93 & 0.80 & 0.71 & 0.31 \\
\hline
\end{tabular}

DAS: Days after storage

Table.4 Effect of different packaging materials on ' $\mathrm{pH}$ ' in Kinnow

\begin{tabular}{|c|c|c|c|c|c|}
\hline \multirow{2}{*}{ Treatments } & \multicolumn{5}{|c|}{ pH } \\
\cline { 2 - 6 } & $\mathbf{5 ~ D A S}$ & $\mathbf{1 0} \mathbf{D A S}$ & $\mathbf{1 5} \mathbf{D A S}$ & 20 DAS & 25 DAS \\
\hline $\mathrm{T}_{1}$ & 3.90 & 4.10 & 4.30 & 0.00 & 0.00 \\
\hline $\mathrm{T}_{2}$ & 3.46 & 3.76 & 3.87 & 4.00 & 0.00 \\
\hline $\mathrm{T}_{3}$ & 3.67 & 3.86 & 3.83 & 3.98 & 4.13 \\
\hline $\mathrm{T}_{4}$ & 3.65 & 3.81 & 3.91 & 3.97 & 0.00 \\
\hline $\mathrm{T}_{5}$ & 3.42 & 3.72 & 3.97 & 4.03 & 0.00 \\
\hline $\mathrm{T}_{6}$ & 3.58 & 3.80 & 3.86 & 3.94 & 4.06 \\
\hline $\mathrm{T}_{7}$ & 3.70 & 3.88 & 4.00 & 4.10 & 0.00 \\
\hline $\mathrm{T}_{8}$ & 3.56 & 3.78 & 3.96 & 4.02 & 0.00 \\
\hline $\mathrm{T}_{9}$ & 3.72 & 3.87 & 3.98 & 4.10 & 0.00 \\
\hline $\mathrm{T}_{10}$ & 3.54 & 3.73 & 3.90 & 4.12 & 0.00 \\
\hline $\mathrm{T}_{11}$ & 3.47 & 3.69 & 3.91 & 4.08 & 4.17 \\
\hline SE(d) & 0.08 & 0.08 & 0.08 & 0.08 & 0.04 \\
\hline CD $(\mathbf{0 . 0 5 \% )}$ & 0.16 & 0.17 & 0.17 & 0.16 & 0.08 \\
\hline
\end{tabular}

DAS: Days after storage 
Table.5 Effect of different packaging materials on 'TSS: Acid ratio' in Kinnow

\begin{tabular}{|c|c|c|c|c|c|}
\hline \multirow{2}{*}{ Treatments } & \multicolumn{5}{|c|}{ TSS: Acid ratio } \\
\cline { 2 - 6 } & 5 DAS & 10 DAS & 15 DAS & 20 DAS & 25 DAS \\
\hline $\mathrm{T}_{1}$ & 8.69 & 10.56 & 15.19 & 0.00 & 0.00 \\
\hline $\mathrm{T}_{2}$ & 8.41 & 9.82 & 11.73 & 12.81 & 0.00 \\
\hline $\mathrm{T}_{3}$ & 9.17 & 9.91 & 11.31 & 12.89 & 15.38 \\
\hline $\mathrm{T}_{4}$ & 8.08 & 9.32 & 10.52 & 11.48 & 0.00 \\
\hline $\mathrm{T}_{5}$ & 8.56 & 9.95 & 11.46 & 12.69 & 0.00 \\
\hline $\mathrm{T}_{6}$ & 8.85 & 9.91 & 10.95 & 11.96 & 14.75 \\
\hline $\mathrm{T}_{7}$ & 8.71 & 9.46 & 10.93 & 11.97 & 0.00 \\
\hline $\mathrm{T}_{8}$ & 8.70 & 10 & 10.91 & 12.55 & 0.00 \\
\hline $\mathrm{T}_{9}$ & 8.60 & 10.09 & 11.80 & 13.18 & 0.00 \\
\hline $\mathrm{T}_{10}$ & 8.41 & 9.73 & 11.28 & 12.42 & 0.00 \\
\hline $\mathrm{T}_{11}$ & 8.86 & 10.41 & 11.61 & 12.93 & 16.05 \\
\hline SE(d) & 0.18 & 0.21 & 0.24 & 0.25 & 0.15 \\
\hline CD $(\mathbf{0 . 0 5 \% )}$ & 0.37 & 0.43 & 0.51 & 0.51 & 0.31 \\
\hline
\end{tabular}

DAS: Days after storage

Table.6 Effect of different packaging materials on 'Total Sugars (\%)' in Kinnow

\begin{tabular}{|c|c|c|c|c|c|}
\hline \multirow{2}{*}{ Treatments } & \multicolumn{5}{|c|}{ Total Sugars $(\%)$} \\
\cline { 2 - 6 } & 5 DAS & 10 DAS & 15 DAS & 20 DAS & 25 DAS \\
\hline $\mathrm{T}_{1}$ & 5.82 & 5.92 & 6.37 & 0.00 & 0.00 \\
\hline $\mathrm{T}_{2}$ & 5.39 & 5.48 & 5.62 & 6.25 & 0.00 \\
\hline $\mathrm{T}_{3}$ & 5.51 & 5.58 & 5.64 & 6.19 & 5.95 \\
\hline $\mathrm{T}_{4}$ & 5.35 & 5.43 & 5.60 & 5.71 & 0.00 \\
\hline $\mathrm{T}_{5}$ & 5.37 & 5.53 & 5.50 & 5.69 & 0.00 \\
\hline $\mathrm{T}_{6}$ & 5.40 & 5.61 & 5.67 & 5.78 & 5.88 \\
\hline $\mathrm{T}_{7}$ & 5.25 & 5.45 & 5.73 & 5.75 & 0.00 \\
\hline $\mathrm{T}_{8}$ & 5.41 & 5.54 & 5.70 & 6.21 & 0.00 \\
\hline $\mathrm{T}_{9}$ & 5.36 & 5.44 & 5.57 & 5.90 & 0.00 \\
\hline $\mathrm{T}_{10}$ & 5.43 & 5.49 & 5.81 & 5.92 & 0.00 \\
\hline $\mathrm{T}_{11}$ & 5.40 & 5.50 & 5.78 & 5.85 & 6.12 \\
\hline SE(d) & 0.11 & 0.12 & 0.12 & 0.12 & 0.06 \\
\hline CD (0.05\%) & 0.23 & 0.24 & 0.25 & 0.25 & 0.12 \\
\hline
\end{tabular}

DAS: Days after storage 
Table.7 Effect of different packaging materials on 'Reducing Sugars (\%)' in Kinnow

\begin{tabular}{|c|c|c|c|c|c|}
\hline \multirow{2}{*}{ Treatments } & \multicolumn{5}{|c|}{ Reducing Sugars (\%) } \\
\cline { 2 - 6 } & $\mathbf{5}$ DAS & 10 DAS & 15 DAS & 20 DAS & 25 DAS \\
\hline $\mathrm{T}_{1}$ & 2.93 & 3.21 & 3.78 & 0.00 & 0.00 \\
\hline $\mathrm{T}_{2}$ & 3.31 & 3.37 & 3.57 & 4.09 & 0.00 \\
\hline $\mathrm{T}_{3}$ & 3.20 & 3.26 & 3.80 & 4.27 & 3.14 \\
\hline $\mathrm{T}_{4}$ & 3.27 & 3.22 & 3.75 & 3.80 & 0.00 \\
\hline $\mathrm{T}_{5}$ & 3.41 & 3.42 & 3.47 & 3.61 & 0.00 \\
\hline $\mathrm{T}_{6}$ & 3.35 & 3.51 & 3.93 & 3.10 & 3.83 \\
\hline $\mathrm{T}_{7}$ & 3.51 & 4.01 & 3.91 & 3.80 & 0.00 \\
\hline $\mathrm{T}_{8}$ & 3.19 & 3.37 & 3.81 & 3.54 & 0.00 \\
\hline $\mathrm{T}_{9}$ & 3.25 & 4.11 & 3.78 & 4.11 & 0.00 \\
\hline $\mathrm{T}_{10}$ & 3.11 & 3.19 & 3.62 & 3.70 & 0.00 \\
\hline $\mathrm{T}_{11}$ & 3.35 & 3.46 & 4.16 & 2.93 & 3.26 \\
\hline SE(d) & 0.07 & 0.07 & 0.08 & 0.07 & 0.03 \\
\hline CD $(\mathbf{0 . 0 5 \% )}$ & 0.14 & 0.15 & 0.16 & 0.15 & 0.06 \\
\hline
\end{tabular}

DAS: Days after storage

Table.8 Effect of different packaging materials on 'Non-Reducing Sugars (\%)' in Kinnow

\begin{tabular}{|c|c|c|c|c|c|}
\hline \multirow{2}{*}{ Treatments } & \multicolumn{5}{|c|}{ Non-Reducing Sugars (\%) } \\
\cline { 2 - 6 } & $\mathbf{5 ~ D A S}$ & $\mathbf{1 0} \mathbf{D A S}$ & $\mathbf{1 5} \mathbf{D A S}$ & 20 DAS & 25 DAS \\
\hline $\mathrm{T}_{1}$ & 2.89 & 2.71 & 2.59 & 0.00 & 0.00 \\
\hline $\mathrm{T}_{2}$ & 2.08 & 2.11 & 2.05 & 2.16 & 0.00 \\
\hline $\mathrm{T}_{3}$ & 2.31 & 2.32 & 1.84 & 1.92 & 2.81 \\
\hline $\mathrm{T}_{4}$ & 2.08 & 2.21 & 1.85 & 1.91 & 0.00 \\
\hline $\mathrm{T}_{5}$ & 1.96 & 2.11 & 2.03 & 2.08 & 0.00 \\
\hline $\mathrm{T}_{6}$ & 2.05 & 2.10 & 1.74 & 2.68 & 2.05 \\
\hline $\mathrm{T}_{7}$ & 1.74 & 1.44 & 2.02 & 1.95 & 0.00 \\
\hline $\mathrm{T}_{8}$ & 2.22 & 2.17 & 1.89 & 2.67 & 0.00 \\
\hline $\mathrm{T}_{9}$ & 2.11 & 1.33 & 1.79 & 1.79 & 0.00 \\
\hline $\mathrm{T}_{10}$ & 2.32 & 2.30 & 2.19 & 2.22 & 0.00 \\
\hline $\mathrm{T}_{11}$ & 2.05 & 2.04 & 1.62 & 2.92 & 2.86 \\
\hline $\mathbf{S E}_{(\mathbf{d})}$ & 0.04 & 0.04 & 0.04 & 0.04 & 0.03 \\
\hline CD $(\mathbf{0 . 0 5 \%})$ & 0.09 & 0.09 & 0.09 & 0.09 & 0.06 \\
\hline
\end{tabular}

DAS: Days after storage 
Table.9 Effect of different packaging materials on 'Sugar: Acid ratio' in Kinnow

\begin{tabular}{|c|c|c|c|c|c|}
\hline \multirow{2}{*}{ Treatments } & \multicolumn{5}{|c|}{ Sugar: Acid ratio } \\
\cline { 2 - 6 } & 5 DAS & 10 DAS & 15 DAS & 20 DAS & 25 DAS \\
\hline $\mathrm{T}_{1}$ & 4.37 & 4.97 & 6.84 & 0.00 & 0.00 \\
\hline $\mathrm{T}_{2}$ & 4.17 & 4.80 & 5.73 & 6.51 & 0.00 \\
\hline $\mathrm{T}_{3}$ & 4.55 & 4.85 & 5.47 & 6.51 & 7.62 \\
\hline $\mathrm{T}_{4}$ & 4.05 & 4.68 & 5.33 & 5.82 & 0.00 \\
\hline $\mathrm{T}_{5}$ & 4.29 & 5.02 & 5.55 & 6.25 & 0.00 \\
\hline $\mathrm{T}_{6}$ & 4.42 & 4.96 & 5.45 & 5.95 & 7.25 \\
\hline $\mathrm{T}_{7}$ & 4.48 & 4.86 & 5.56 & 5.98 & 0.00 \\
\hline $\mathrm{T}_{8}$ & 4.36 & 4.73 & 5.22 & 6.33 & 0.00 \\
\hline $\mathrm{T}_{9}$ & 4.39 & 5.13 & 5.92 & 6.48 & 0.00 \\
\hline $\mathrm{T}_{10}$ & 4.30 & 4.94 & 5.75 & 6.23 & 0.00 \\
\hline $\mathrm{T}_{11}$ & 4.39 & 5.04 & 5.83 & 6.35 & 8.05 \\
\hline SE(d) & 0.09 & 0.10 & 0.12 & 0.12 & 0.07 \\
\hline CD $(\mathbf{0 . 0 5 \% )}$ & 0.19 & 0.21 & 0.25 & 0.26 & 0.15 \\
\hline
\end{tabular}

DAS: Days after storage

The results are in line with findings of Gul et al., (1990) who observed that the effect of Fruitex (wax emulsion) on blood red oranges during room storage found that non-reducing sugars increased during storage. And the treatment $\mathrm{T}_{3}$ retained maximum 'Sugar-Acid ratio' (4.55), which were on par with each other including $\mathrm{T}_{7}$ (4.48) and $\mathrm{T}_{6}(4.42)$ at 5 days after storage. The minimum 'Sugar-Acid ratio' was recorded in $\mathrm{T}_{4}$ (4.05). It was found to be on par with $\mathrm{T}_{2}$ (4.17). At 25days after storage, the observations among various packaging treatments revealed that the fruits under treatment $\mathrm{T}_{11}$ retained maximum 'Sugar-Acid ratio' (8.05). The minimum 'Sugar-Acid ratio' was recorded in $\mathrm{T}_{6}$ (7.25). In rest of the treatments, except $T_{3}$, no fruits were found to be retained for observation.

\section{Acknowledgement}

We are really thankful to Horticulture faculty of Lovely Professional University for their active support, valuable time and advice, whole-hearted guidance, sincere cooperation and pains taking involvement during this study.

\section{References}

Artes-Hernandez, F., Aguayo, E. and Artes, F. 2004. Alternative atmosphere treatments for keeping quality of "Autumn Seedless" table grapes during long- term cold storage. Post-harvest Biol Technol., 31: 59-67.

Artes-Hernandez, F., Tomas-Barberan, F.A and Artes, F. 2006. Modified atmosphere packaging preserves quality of SO2 - free 'Superior seedless' table grapes. Postharvest Biol. Technol., 39(2): 146-154.

Efiuvwere, B.J.O. and Oyelade, J.A. 1991. Biodeteriorative and physicochemical changes in modified atmosphere packaged oranges and the microbial quality of the preserved and unpreserved juice. Trop. Sci., 31(4): 325-333.

El-Hefnawi, S.M. 2002. Effect of some postharvest treatments and type of bagging on some quality parameters of Awais mango fruits during and after cold storage. Zagazig J. Agric. Res., 29(3): 709-726. 
El-Hefnawi, Safaa, S.M., Nomier, A., Hassan A.S.A.and Gad, M.M. 2008.Effect of packaging during cold storage period on guava fruits cv. El-Mamoura. Egypt. $J$. Appl. Sci., 23(3):186-212.

Geeson, J.D., Maddison K. and Browne, K.M. 1981. Modified Atmosphere Packaging of Tomatoes. In: Packaging of Horticultures Produce. AAB/NCAE Residential Meeting, London, p: 8-15.

Gul, S., Ishtiaq, M. and Shah, S.H. 1990. Studies on the effect of storage on the quality of sweet orange. Sarhad J. Aric., 6(5): 433-436.

Haikerwal, S. 2001. Effect of protective coating and individual seal packing on the storage life of Jaffa sweet orange, M.Sc. Thesis, PAU, Ludhiana.

Kader, A.A. 2002. Recommendations for maintaining postharvest quality, Post harvest Technology Research Information Center. Dept of Pomology, Univ. of California. One Shield Ave., Davis, CA, 95616-8683.

Kumar, J., Sharma, R.K. and Singh, R. 1991. Effect of modified atmospheric storage on shelf life of Kinnow mandarin. Haryana J. Horticultural Sci., 20(3/4): 156-160.

Kumar, S. and Chauhan, K.S. 1990. Effect of fungicides and calcium compounds on shelf life of kinnow mandarin. Haryana
J. Horticultural Sci., 19: 102-121.

Mahajan, B.V.C, A.S. Dhatt, and K.S. Sandhu. 2005. Effect of different post harvest treatments on the storage life of kinnow mandarin. $J$. Food Sci. Technol., 42(4): 296-299.

McHugh, T.H., and Senesi, E. 2000. Apple wraps: A novel method to improve the quality and extend the shelf life of fresh-cut apples. J. Food Sci., 65(3): $480-485$.

Panse, V.G. and Sukhtme, P.V. 1985. Statistical methods for Agricultural workers, Indian Council of Agricultural Research, New Delhi.

PHLRD. 2005. Food Loss Status in Nepal, Progress Report, Postharvest Loss Reduction Division, Postharvest Management Directorate, Kathmandu, Nepal, 3.

Piga, A., D`Aquino S., Agabbio, M. and Piergiovanni, L. 2003. Polyethylene film packaging affects quality of Lisbon lemons during long-term storage. Italian J. Food Sci., 9(1): 25-35.

Sonkar, R.K. and Ladaniya, M.S. 1999. Unipacking of Nagpur mandarin fruits with heat shrinkable and stretch cling polyethylene film. In: Proceedings of International Symposium on Citriculture, held at NRC for Citrus, Nagpur, p- 465-468.

\section{How to cite this article:}

Rupinder Singh, Senthil Kumar, Anjil Kumar, Sudhir Pratap, Davinder, Harmanbir Singh and Ajay Kumar. 2017. Studies of Various Packaging Materials and Waxing on Quality Traits of Kinnow. Int.J.Curr.Microbiol.App.Sci. 6(8): 1370-1379. doi: https://doi.org/10.20546/ijcmas.2017.608.167 